\title{
Analisis Model Pembelajaran Jigsaw Terhadap Capaian Keterampilan Service Bawah Bola Voli Pada Kelas Viii SMP Swasta Pencawan School Medan
}

\author{
Karina Bastanta Br Ginting1, Liliana PuspaSari2 \\ 1,2 Sekolah Tinggi Olahraga dan Kesehatan Bina Guna, Indonesia \\ Email : lili.binaguna@gmail.com
}

\begin{abstract}
ABSTRAK
Penelitian ini bertujuan untuk mengetahui bagaiamana pelaksanaan model pembelajaran jigsaw terhadap Hasil Belajar Bola Voli Teknik Service Bawah pada kelas VIII SMP Pencawan School Medan. Konsep yang digagas adalah untuk menemukan pembahasan model pembelajaran sebagai petunjuk proses belajar, kemudian dapat menjadi rekomendasi siswa untuk menerapkan pembelajaran teknik dasar yakni melaksanakan materi servis bawah bola voli.

Penelitian ini menggunakan desain penelitian pada pelaksanaan dilapangan adalah menggunakan desain deskriptif. Desain deskriptif adalah metode kualitatif dengan yang dilaksanakan dengan kemampuan analisis peneliti dalam menghubungkan antar variabel penelitian. Penelitian yang dilaksanakan pada masa pandemi Corona Virus Desease 2019 (Covid-19) yakni melakukan kajian analisis yang bekaitan dengan gaya mengajar dan hasil belajar bola voli. Data penelitian diperoleh melalui kajian analisis secara mendalam pada 3 jurnal nasional tentang model pembelajaran jigsaw, dan 3 jurnal nasional tentang teknik servis bawah bolavoli.

Hasil Analisis terhadap kajian model pembelajaran jigsaw dan teknik sevis bawah bola voli memiliki hubungan pada aspek penerapan proses pembelajaran. Proses pembelajaran yang dimaksud adalah langkah-langkah pada model pembelajaran jigsaw yang merupakan model pembelajaran yang mendorong siswa untu berpikir analisis, dan pada peningkatan keterampilan servis bawah membutuhkan analisis. Jika dikaitkan dengan materi servis bawah bola voli maka jigsaw hanya dapat diterapkan berdasarkan penilaian guru bahwa beberapa siswa memiliki keterampilan servis bawah bola voli.

Simpulan dalam penelitian ini adalah penelitian analisis kajian model pembelajaran jigsaw terhadap hasil servis bawah bola voli untuk sekolah SMP Swasta Pencawan School Medan pada masa Pendemi Corona Virus Desease-19 dilakukan dengan studi pustaka jurnal nasional. Kajian dilakukan dengan menemukan karakteristik model pembelajaran jigsaw dan karakteristik hasil belajar servis bawah bola voli. Berdasarkan analisis yang ditemukan maka dapat disimpulkan bahwa gaya mengajar jigsaw memiliki hubungan dengan teknik belajar servis bawah bola voli dengan kriteria yaitu beberapa siswa memiliki kemampuan pada materi yang diterapkan, sasaran siswa memiliki kriteria yang memiliki sikap disiplin yang baik, dan materi yang akan disampaikan telah disiapkan oleh guru terkait sarana dan prasarana yang dapat digunakan oleh siswa secara mandiri.
\end{abstract}

Kata kunci: Analisis, Jigsaw, Service Bawah, Covid-19

\section{ABSTRACT}


This study aims to determine how the implementation of the jigsaw learning model on the Learning Outcomes of Lower Service Technique Volleyball in class VIII of SMP Pencawan School Medan. The concept that was initiated was to find a discussion of the learning model as a guide for the learning process, then it could be a recommendation for students to apply basic technique learning, namely implementing the volleyball bottom service material.

This study uses a research design in the field implementation using a descriptive design. Descriptive design is a qualitative method which is implemented with the researcher's analytical skills in linking the research variables. Research carried out during the Corona Virus Desease 2019 (Covid-19) pandemic carried out an analytical study related to teaching styles and learning outcomes of volleyball. The research data were obtained through an indepth analysis study in 3 national journals about the jigsaw learning model, and 3 national journals about volleyball bottom serve techniques.

The results of the analysis of the study of the jigsaw learning model and the volleyball bottom line technique have a relationship to the application aspect of the learning process. The learning process in question is the steps in the jigsaw learning model which is a learning model that encourages students to think analytically, and in improving lower service skills requires analysis. If it is related to volleyball bottom serve material then jigsaw can only be applied based on the teacher's assessment that some students have volleyball under serveskills. The conclusion in this study is a research analysis of the study of the jigsaw learning model on the results of the under-service volleyball for the Private Junior High School Pencawan School Medan during the Corona Virus Desease-19 epidemic was carried out by studying national journal literature. The study was carried out by finding the characteristics of the jigsaw learning model and the characteristics of the learning outcomes of volleyball bottom serve. Based on the analysis found, it can be concluded that the jigsaw teaching style has a relationship with the volleyball bottom serve learning technique with the criteria that some students have the ability to the material applied, the target students have criteria that have a good disciplinary attitude, and the material to be delivered has been prepared. by teachers related to facilities and infrastructure that can be used by studentsindependently.

\section{Keywords: Analysis, Jigsaw, Service Below, Covid-19}

\section{PENDAHULUAN}

Sebagai sekolah yang memiliki fasilitas serta perlengkapan permainan bola voli, guru memiliki harapan bahwa siswa di sekolah SMP Swasta Pencawan School Medan memiliki kemampuan bermian bola voli yang memadai sehingga mampu untuk mengikuti pertandingan di luar sekolah. Hal ini menunjukkan juga bawah siswa masih memilki kemampuan bermain bola voli yang rendah. Salah satu teknik dasar bola voli yang sangat dibutuhkan akan teknik service bawah. Servis bawah adalah gerakan yang dilakukan dengan mengarahkan bola ke arah lawan dengan menggerakkan/memukul melalui salah satu tangan dari bawah ke arah bola, sehingga hasil pukulan akan membentuk parabola dan melewati net. Servis digunakan untuk memulai pertandingan dalam bola voli, sehingga bagi para pemaian yang akan bermain bola voli, teknik yang paling awal harus dikuasai adalah teknik servis bawah.

Hasil pre test yang pernah dilakukan oleh guru PJOK terhadap kelas VIII, ada 2 kelas dari 5 kelas yang memiliki kemampuan servis lebih baik yaitu kelas VIII-A dan VIII-B. Kedua kelas 
tersebut lebih aktif dalam memanfaatkan lapangan walapun masih dengan teknik yang belum baik. Hasil pre test yang diperoleh adalah siswa pada kelas VIII-A dari 20 orang yang memiliki kemampuan dalam melakukan servis bawah dengan baik adalah berjumlah 3 orang, dan pada kelas VIII-B dari 32 siswa yang mampu servis bawah adalah 5 orang. Sehingga pada saat kedua kelas tersebut bermain boa voli, hanya yang mampu servis saja yang memulai pertadingan dengan servis bawah.

Berdasarkan keterangan di atas, maka sangat penting jika dilakukan pendekatan belajar pada saat pembelajaran bola untuk meningkatkan kemampuan keterampilan siswa dalam bermain bola voli yaitu terkhusus servis bawah. Dalam hal ini penerapan melalui pendekatan belajar memiliki tujuan untuk mempengaruhi kompetensi dan proses belajar anak dengan metode terprogram (programmed instruction) dan metode kreativitas dan pemecahanmasalah.

Pendekatan belajar Penjas yang dapat digunakan adalah jigsaw. Jigsaw adalah model pembelajaran yang diterapkan dengan cara memahami kemampuan dan pengalaman siswa terlebih dahulu dan kemudian membantu siswa mengaktifkan skema tersebut agar materi pembelajaran menjadi lebih bermakna. Guru juga banyak memberikan kesempatan pada siswa untuk mengolah informasi dan meningkatkan keterampilan berkomunikasi. Pembelajaran penjas dengan menggunakan model jigsaw, guru membentuk kelompok dan masing-masing kelompok mendapatkan bagian/subtopik yang akan dibahas dan didiskusikan secara bersama dalam kelompok, kemudian guru membentuk "kelompok ahli" (expert group) dalam setiap kelompok tersebut. Misalnya, kelompok yang memperoleh bagian/subtopik passing akan melakukan pembahasan, diskusi, dan latihan passing secara khusus. kemudian siswa (dapat lebih dari satu) yang kompeten dan cepat belajar dalam kelompok akan dijadikan sebagai ahli untuk dikirim kepada kelompok lain (dapat pula tidak dikirim ke kelompok lain, namun kelompok lain yang akan melakukan kunjungan kepada siswa/kelompok ahli tersebut). Para kelompok ahli tersebut kemudian berdiskusi membahas masalah yang sama, setelah selesai kemudian kelompok ahli pulang kembali ke kelompok asalnya masing-masing untuk melakukan diskusi kembali dan menjelaskan apa yang baru saja dipelajarinya (dari "kelompok ahli") kepada rekan-rekan kelompoknya yang semula.

Perkembangan yang terjadi saat ini hingga Agustus 2020 maka situasi pembelajaran hanya dilakukan melalui dalam jaringan (daring) sehingga pelaksanaan pembelajaran tidak dapat dilakukan secara langsung. Pendidikan Jasmani di Sekolah tidak efektif dilakukan secara daring sehingga pelaksanaan penelitian dilakukan berdasarkan analisis model pembelajaran yang akan diterapkan terhadap hasil belajar Bola Voli Teknik Service bawah pada siswa kelas VIII SMP Swasta Pencawan SchoolMedan.

\section{METODE PENELITIAN}

Pendekatan penelitian yang dterapkan adalah kualitatif dengan desain penelitian deskriptif. Desain deskriptif adalah metode kualitatif dengan yang dilaksanakan dengan kemampuan analisis peneliti dalam menghubungkan antar variabel penelitian. Penelitian dengan pendekatan kualitatif memiliki karakteristik naturalistik yaitu penelitian yang memiliki latar aktual sebagai sumber langsung data dan peneliti merupakan instrumen kunci. 
Pelaksanaan dalam penelitian ini adalah model pembelajaran jigsaw untuk melihat kajian teoritis terhadap keterampilan teknik service bawah bola voli. Proses pelaksanaan dengan melakukan studi pustaka pada pembahasan keterampilan service bawah bola voli dan model pembelajaran jigsaw. Hasil kajian analisis kemudian akan dijadikan bahan rujukan pelaksanan pembelajaran PJOK pada Sekolah SMP Swasta Pencawan SchoolMedan.

(Moleong, 2007) menjelaskan bahwa "bentuk data utama dalam penelitian kualitatif ialah kata-kata, dan tindakan, selebihnya adalah data tambahan seperti dokumen dan lain-lain". Data yang diperoleh berupa tulisan-tulisan dari kajian model pembelajaran jigsaw dan hasil belajar bola voli service bawah pada kelas VIII SMP Swasta Pencawan Medan, kemudian data dideskripsikan untuk menjawab rumusan masalah yaitu "Bagaiaman pelaksanaan gaya mengajar jigsaw terhadap Hasil Belajar Bola Voli Teknik Service Bawah pada kelas VIII SMP Swasta Pencawan School Medan".

\section{HASIL DAN PEMBAHASAN}

Berdasarkan penjelasan di atas, dapat disimpulkan bahwa model jigsaw diterapkan dengan cara memahami kemampuan dan pengalaman siswa terlebih dahulu dan kemudian membantu siswa mengaktifkan skema tersebut agar materi pembelajaran menjadi lebih bermakna. Guru juga banyak memberikan kesempatan pada siswa untuk mengolah informasi dan meningkatkan keterampilan berkomunikasi.

pembelajaran PJOK dengan menggunakan model jigsaw, guru membentuk kelompok dan masing-masing kelompok mendapatkan bagian/subtopik yang akan dibahas dan didiskusikan secara bersama dalam kelompok, kemudian guru membentuk "kelompok ahli" (expert group) dalam setiap kelompok tersebut. Misalnya, kelompok yang memperoleh bagian/subtopik passing akan melakukan pembahasan, diskusi, dan latihan passing secara khusus dan begitu pula dengan kelompok lain dengan bagian/subtopik lain seperti service, kemudian siswa (dapat lebih dari satu) yang kompeten dan cepat belajar dalam kelompok akan dijadikan sebagai ahli untuk dikirim kepada kelompok lain (dapat pula tidak dikirim ke kelompok lain, namun kelompok lain yang akan melakukan kunjungan kepada siswa/kelompok ahli tersebut). Para kelompok ahli tersebut kemudian berdiskusi membahas masalah yang sama, setelah selesai kemudian kelompok ahli pulang kembali ke kelompok asalnya masing-masing untuk melakukan diskusi kembali dan menjelaskan apa yang baru saja dipelajarinya (dari "kelompok ahli") kepada rekan- rekan kelompoknya yang semula.

Mengenai hal di atas dapat dijabarkan bahwa model pembelajaran jigsaw pada dasarnya adalah pembelajaran yang dilakukan dengan membentuk kelompok ahli (expert) yang dijadikan sebagai proses pembelajaran dalam kelompok dan diskusi untuk memvariasikan dan mengkemas pembelajaran agar lebih menarik.

Langkah-langkah dalam menerapkan model pembelajaran jigsaw adalah sebagai berikut 
1. Guru memberikan penjelasan tentang materi pembelajaran kepada siswa, serta model pembelajaran yang akanditerapkan.

2. Guru membagi kelompok masing-masing terdiri dari 4-5orang.

3. Masing-masing siswa dalam kelompok akan diberikan tugas berupa materi yang diberikan guru berdasarkan kesepakatan dalamkelompok.

4. Masing-masing siswa melakukan diskusi (latihan) di dalam kelompoknya masing-masing.

5. Masing-masing siswa di dalam kelompok akan di sebar pada siswa lain yang sama tugasnya (tim ahli/expert) untuk berdiskusi secara mendalam (menganalisi gerakan teknik secara kelompok).

6. Siswa kembali kepada kelompoknya masing-masing untuk berdiskusi kembali pada kelompok asalnya.

langkah-langkah tersebut dapat dimodifikasi oleh guru dalam pembelajaran, namun tidak menghilangkan karakter kelompok ahli dalam proses pembelajaran tersebut.

4.3. Pembahasan tentang Teknik Service Bawah BolaVoli

Servis bawah bola voli ialah jenis pukulan perrnulaannya dari perpanjangan garis belakang dengan memukul bola dari bagian tengah tubuh sebagai usaha untuk memulai permainan. Servis dilakukan dengan merangkai gerakan antar organ tubuh yaitu tangan, kaki, badan, dan kepala untuk memukul menjadi satu gerakan yang tidak terputus-putus. Ketika sedang bersiap diri melakukan servis, pemain dapat berdiri dimana saja di sepanjang dan di belakang garis ujung lapangan, lutut ditekuk, dan berat badan berada bertumpu dikakibelakang.

Teknik servis bawah yang terdapat dalam permainan bola voli terdiri dari beberapa macam,: 1) Floating serve (servis mengapung), 2) Overhand Service (hook service), 3) jump service. Jenis scrvis atas pada permainan bola voli juga dapat diklasifikusikan berdasarkan putaran hob. Puturan bola yang dihasilkan merupakan pengaruh yang ditimbulkan olch adanya gerakan telapak tangan pada saat melakukan servis. e) Float. Back spill adalah servis dengan arah putaran bola ke belakang. Apabila arah putaran bola hasil scrvis tersebut kearah samping dalam disebut inside spin, sedangkan ke arah samping luar disebut outside spin. Top spin merupakan servis dengan arah putaran bola ke depan, sedangkan float merupakan servis bola mengapung (tanpaputaran).

Teknik dasar servis terdiri dari tiga tahap yaitu: a) sikap permulaan, b) gerak pelaksanaan, c) gerak lanjutan (follow throughi). Teknik pelaksanaan tiap tahapan servis at as adalah sebagai berikut :

1) sikap permulaan 
Berdiri di daerah servis menghadap kelapangan, bagi yang tidak kidal kaki kiri sebelah depan dan jika kidal posisi kaki sebaliknya, namun ada juga pemain berdiri dengan kedua kaki sejajar dengan menghadap ke net. Bola dipegang tang an kiri setinggi kepala, tangan kanan menggenggam atau juga dengan telapak tangan terbuka.

2) SikapPelaksanaan

Bola dilarnbungkan di depan atas lebih tinggi dari kepala, tangan kanan segera memukul bola pada bagian tengan belakang dari bola.

3) Gerak lanjutan

Gerak lanjutan lengan pemukul harus segaris dengan gaya yang dihasilkan atau didorong ke depan.

\section{Pembahasan}

Analisis terhadap kajian model pembelajaran jigsaw dan teknik sevis bawah bola voli memiliki hubungan pada aspek penerapan proses pembelajaran. Proses pembelajaran yang dimaksud adalah langkah-langkah pada model pembelajaran jigsaw yang merupakan model pembelajaran yang mendorong siswa untu berpikir analisis, dan pada peningkatan keterampilan servis bawah membutuhkan analisis.

Model pembelajaran jigsaw memiliki karakter sebagai model pembelajaran yang memiliki penguasaan terhadap teknik atau materi yang akan diajarkan dalam kelas. Penguasaan yang dimaksud adalah pada beberapa siswa, materi sudah dipelajari dan dikuasai terlebih dahulu sebelum materi diajarkan oleh guru. Situasi ini jelas sangat langkah terdapat pada setiap sekolah dan masing-masing siswa. Namun, pada umumnya bagi sekolah dengan minat belajar siswa yang tinggi dapat memberikan dampak tercapainya kompetensi dasar yang diharapkan. Model jigsaw diterapkan dengan cara memahami kemampuan dan pengalaman siswa terlebih dahulu dan kemudian membantu siswa mengaktifkan skema tersebut agar materi pembelajaran menjadi lebih bermakna. Guru juga banyak memberikan kesempatan pada siswa untuk mengolah informasi dan meningkatkan keterampilan berkomunikasi.

Jigsaw disebut juga sebagai kelompok ahli, sebagaimana penjelasan di atas bahwa siswa telah mempelajari atau mengetahui terlebi dahulu materi yang akan diajarkan. Penerapannya dapat dilakukan dengan guru membentuk kelompok dan masing-masing kelompok mendapatkan bagian/subtopik yang akan dibahas dan didiskusikan secara bersama dalam kelompok, kemudian guru membentuk "kelompok ahli" (expert group) dalam setiap kelompok tersebut. Misalnya, kelompok yang memperoleh bagian/subtopik passing akan melakukan pembahasan, diskusi, dan latihan passing secara khusus dan begitu pula dengan kelompok lain dengan bagian/subtopik lain seperti service, kemudian siswa (dapat lebih dari satu) yang kompeten dan cepat belajar dalam kelompok akan dijadikan sebagai ahli untuk dikirim kepada kelompok lain (dapat pula tidak dikirim ke kelompok lain, namun kelompok lain yang akan melakukan kunjungan kepada siswa/kelompok ahli tersebut).

Jika dikaitkan dengan materi servis bawah bola voli maka jigsaw hanya dapat diterapkan berdasarkan penilaian guru bahwa beberapa siswa memiliki keterampilan servis bawah bola voli. Hal yang paling mudah untuk melihat itu adalah : 1) melalui penilaian awal yang dilakukan guru dengan teknik permainan; dan 2) informasi dan pengakuan siswa 
bahwa siswa tersebut merupakan atlet bola voli. Hal ini juga terdapat pada beberapa sekolah tertentu saja yang artinya tidak semua sekolah memiliki kriteria tersebut.

Penerapannya model pembelajaran jigsaw dapat diterapkan pada seluruh tingkat sekolah mulai dari sekolah dasar dan sederajat, sekolah menengah pertama dan sederajat, serta sekolah menengah atas dan sederajat. Namun, pada setiap sekolah memiliki ketentuan khusus dalam penerapkan model pembelajaran jigsaw yaitu:

1) Telah dilakukan observasi terkait siswa yang memiliki kemampuan pada materi yangditerapkan.

2) Sasaran siswa memiliki kriteria yang memiliki sikap disiplin yangbaik.

3) Materi yang akan disampaikan telah disiapkan oleh guru terkait sarana dan prasarana yang dapat digunakan oleh siswa secaramandiri.

\section{KESIMPULAN}

Penelitian analisis kajian model pembelajaran jigsaw terhadap hasil belajar servis bawah bola voli untuk sekolah SMP Swasta Pencawan School Medan pada masa Pendemi Corona Virus Desease-19 dilakukan dengan studi pustaka jurnal nasional. Kajian dilakukan dengan menemukan karakteristik model pembelajaran jigsaw dan karakteristik hasil belajar servis bawah bola voli. Berdasarkan analisis yang ditemukan maka dapat disimpulkan bahwa gaya mengajar jigsaw memiliki hubungan dengan teknik belajar servis bawah bola voli dengan kriteria yaitu beberapa siswa memiliki kemampuan pada materi yang diterapkan, sasaran siswa memiliki kriteria yang memiliki sikap disiplin yang baik, dan materi yang akan disampaikan telah disiapkan oleh guru terkait sarana dan prasarana yang dapat digunakan oleh siswa secara mandiri.

Penerpaan model pembelajarn jigsaw pada hasil belajar teknik servis bawah bola voli dapat diterapkan kepada seluruh tingkatan sekolah mulai dari sekolah dasar dan sederajat, sekolah menengah pertama dan sederajat, serta sekolah menengah atas dan sederajat dengan kriteria jigsaw. Berdasarkan hal tersebut maka model pembelajaran dapat direkomendari penerapannya pada sekolah SMP Pencawan School Medan dalam proses pembelajaran Pendidikan Jasmani Olahraga dan Kesehatan.

\section{DAFTAR PUSTAKA}

Adhull, F. 2014. Passing dan Catching : Basket. http://fuji17- sharing.blogspot.co.id [diakses 12 Pebruari 2016]

Akilan. N. 2014. Effect Of Basketball Specific Endurance Circuit Training On Body Composition And Aerobic Capacity Of High School Male Basketball Players. International Journal of Physical Education, Fitness and Sport. 3(1):15-21

Amber,V.Bola Basket Petunjuk Untuk Pelatihdan Pemain.Bandung: C.V. Pionir Jaya 
Azmin,N.H. 2016. Effect of the Jigsaw-Based Cooperative Learning Method on Student Performance in the General Certificate of Education Advanced- Level Psychology: An Exploratory Brunei Case Study. International Education Studies. 9(1): 91-106

Azwar, S. 2014. Reliabilitas dan Validitas. Yogyakarta: Pustaka Pelajar

Azzulfa, Y. 2015. http://kumpulantugassekolahdankuliah.blogspot.co.id/2015/01/ kelebihan-dan-kekurangan-pembelajaran.html [diakses 17 Maret 2016]

Badan Standar Nasional Pendidikan. 2006. Panduan Penyusunan Kurikulum Tingkat Satuan Pendidikan Jenjang Pendidikan Dasar Dan Menengah. Jakarta: BSNP

Creswell, J.W. 2014. Research Design Pendekatan Kualitatif, Kuantitatif, dan Mixed. Yogyakarta: Pustaka Pelajar

Dhara, S. \& Ghosh,S.N. 2015. A Comparative Study of Explosive Strength and Selective Anthropometric Variables between the Basketball and Volleyball Players. The International Journal Of Humanities \& Social Studies. 3(4):159-163

Fenanlampir, A. \& Faruq, M.M. 2015. Tes dan pengukuran dalam olahraga. Yogyakarta: CV ANDI

Gaggioli, A., Morganti, L., Mondoni, M., \& Antonietti, A. 2013."Benefits of Combined Mental and Physical Training in Learning a Complex Motor Skill in Basketball". Journal Scientific Research. 4(9A2): 1-6

Gunawan, M.A. 2013. Statistik untuk Penelitian Pendidikan. Yogyakarta: Parama Publishing Huda, M. 2014. Model-Model Pengajaran dan Pembelajaran. Yogyakarta: Pustaka Pelajar

Indra Malik. 2015. Materi Bola Basket. https://ferimoeroesz.wordpress.com/2015/02/ [diakses 12 Pebruari2016]

Kingbalax. 2014. Bola Basket Terbaik Indoor dan Outdoor (Bagian 2). pivotbolabasket.wordpress.com [diakses 17 November 2015]

Komarudin. 2016. Penilaian Hasil Belajar Pendidikan Jasmani dan Olahraga.

Bandung: PT Remaja Rosdakarya

Kosasi, D. 2008. Fundamental Basketball A First Step To Success. Semarang: Karangturi Media

Ling, J., dan Catling, J. 2012. Psikologi Kognitif. Terjemahan Noormalasari Fajar Widuri. :Erlangga. 
Milenković, D. \& Stanojević, I. 2014."Relations Between Motoric Abilities and Specific Motoric Basketball Skills in Physical Education Classes". (IJCRSEE) International Journal of Cognitive Research in Science, Engineering and Education. 2(1): 19-24

Mohaimin, A. \& Kishore, Y. 2014. Construction of Dribbling Control Ability Test for Basketball. International Journal of Physical Education, Sports and Health. 1(2): 1416

Mosston, M. \& Ashworth, S. 2008. TeachingPhysicalEducation. : First Online Edition

Muhajir. 2007. Pendidikan Jasmani Olahraga dan Kesehatan. Jakarta: Erlangga Oliver, J. 2009. Dasar-Dasar Bola Basket. Terjemahan Wawan Eko Yulianto. Jakarta: Pakar Raya.

Olympia, L., Eva, P., Panagiotis, A., \& Argyris, K. 2014. Proposal of a physical education program with multicultural elements in the Secondary Education and evaluation of student satisfaction. International Journal of Education and Research. 2(12): 165-180

Prusak, K.A. 2005. Permainan BolaBasket. Terjemahan : Citra AjiParama.

Purwanto, M.N. 2012. Prinsip-Prinsip dan Teknik Evaluasi Pengajaran. Bandung: Rosda

Rahayu, E.T. 2013. Strategi Pembelajaran Pendidikan Jasmani. Bandung: Alfabeta

Rahyubi, H. 2014. Teori-Teori Belajar dan Aplikasi Pembelajaran Motorik. Bandung: Nusa Media

Riyadi, M.F. 2013. “Keefektifan Model Pembelajaran Example Non-Example Terhadap Hasil Belajar Menulis Deskripsi Siswa Kelas IV SDN Randugunting 4 Kota Tegal”. Skripsi. Semarang: Pendidikan Guru SekolahDasar

Romadhon, W.K. 2013. "Pengaruh Pembelajaran Jigsaw dan pembelajaran Resiprokal Terhadap Gerak Dasar Lay Up dalam Bermain Bolabasket". Jurnal Penelitian. Lampung: Keguruaan dan Ilmu Pendidikan

Rosdiani, D. 2013. Perencanaan Pembelajaran dalam Pendidikan Jasmani dan Kesehatan. Bandung: Alfabeta

Sari, I. E. P. (2020). Efforts to Improve Learning Outcomes passing Down Volleyball Variations Through Learning and Modified Ball On Private Junior High School eighth grade students Perbaungan Satria Dharma School Year 2019/2020: Efforts to Improve Learning Outcomes passing Down Volleyball Variations Through Learning and Modified Ball On Private Junior High School eighth grade students Perbaungan Satria Dharma School Year 2019/2020. Journal of Midwifery and Nursing, 2(1), 173176. 
Sachanidi,M., Apostolidis,N., Chatzicharistos,D,.\& Bolatoglou,T. 2013."Passing Efficacy of Young Basketball Players: Test or Observation?". International Journal of Performance Analysis in Sport. 13():403-412

Sudijono, A. 2012. Pengantar Evaluasi Pendidikan . Jakarta: Rajawali Pers SudiraMP,P.2006.KurikulumTingkatSatuanPendidikanSMK.Jakarta: Departemen Pendidikan Nasional.

Sugiyono. 2011. Metode Penelitian Kombinasi (Mixed Methodes). Bandung: Afabeta Syah, M. 2013. Psikologi Belajar. Jakarta: RajaGrafindo Persada

Syuhada, M. 2013. "Hubungan Antara Power Otot Lengan Bahu, Kekuatan Otot Tungkai, Koordinasi Mata Tangan Dengan Kemampuan Free Throw Pada Peserta Ekstrakurikuler Bolabasket Di SMA N 1 Ngemplak Sleman". Skripsi. Yogyakarta: Ilmu Keolahragaan

Tran, V.D. 2014. The Effects of Cooperative Learning on the Academic Achievement and Knowledge Retention. International Journal of Higher Education. 3(2): 131-140

Undang-Undang Republik Indonesia Nomor 3 Tahun 2005 dan Peraturan Pemerintah Republik Indonesia Tahun 2007 tentang Sistem Keolahragaan Nasional. 2007.Bandung: Diperbanyak oleh Citra Umbara

Uno, H.B. \& Mohamad, N. 2011. Belajar dengan Pendekatan PAILKEM. Jakarta: P.T. Bumi Aksara

Usman, H. \& Akbar, R.P.S. 2011. Pengantar Statistik. Jakarta: Bumi Aksara Warsono \& Hariyanto. 2014. Pembelajaran Aktif. Bandung: Rosda

Yu, K.T., Su, Z.X., \& Zhuang, R.C. 2008. An Exploratory Study of Long-Term Performance Evaluation for Elite Basketball Players. International Journal of Sports Science and Engineering. 2(1): 195-203 (Produser). 2014. "Penjasorkes Bola Volley". (Rekaman Video). Jakarta: Direktorat SMA danPUSTEKKOM 